\author{
Aleksander Surdej \\ Katedra Studiów Europejskich \\ Uniwersytet Ekonomiczny w Krakowie
}

\title{
Rola muzeów w rozwoju społeczno-gospodarczym państwa
}

\section{Streszczenie}

Celem artykułu jest analiza przesłanek teoretycznych i czynników empirycznych, które wyjaśniają wzrost społecznego i gospodarczego znaczenia muzeów we współczesnych państwach. Przedstawiono argumenty i dane, które pozwalają zrozumieć, jak ewolucja funkcji muzeum tworzy bodźce do rozszerzania zakresu ich działalności (typów usług) oraz różnicowania źródeł finansowania, co z kolei przyczynia się do wzrostu ekonomicznego znaczenia muzeów.

W artykule wykorzystano dane dotyczące rozwoju sektora muzealnego w wybranych wysoko rozwiniętych państwach. Wskazano także problemy z określeniem optymalnego poziomu i metod publicznego finansowania muzeów oraz źródła problemów w oszacowaniu społecznych korzyści płynących z funkcjonowania muzeów.

Artykuł ma charakter teoretyczno-empiryczny i służy wypracowaniu podejścia do wyjaśnienia obserwowanego wzrostu liczby funkcjonujących muzeów. Z analizy wynika, że wzrost ilościowy wiąże się z poszerzeniem funkcji muzeów.

Słowa kluczowe: ekonomiczna analiza instytucji kultury, ekonomia muzeów, analiza kosztów i korzyści, przemysł kreatywny.

\section{Wprowadzenie}

Współcześnie ekonomiści coraz częściej zwracają uwagę na kwestię rozwoju gospodarczego w odróżnieniu od wcześniejszej wyłącznej koncentracji na czynnikach wzrostu gospodarczego [Stiglitz, Sen i Fitoussi 2013]. Ci, którzy nie 
śledzą debat ekonomicznych, mogą uznać taką zmianę za manewr semantyczny i w gruncie rzeczy nieistotny. Tak jednak nie jest. Przejście od analiz czynników wzrostu gospodarczego mierzonego wielkością dostarczonych dóbr i usług, a więc w wymiarze ilościowych i głównie materialnym, do analiz problemów rozwoju gospodarczego, w którym, oprócz produkcji rynkowej, ważne stają się jej konsekwencje przyrodnicze, społeczne, kulturowe i temporalne (w tym międzypokoleniowe) rodzi poważne konsekwencje teoretyczne. W perspektywie rozwoju gospodarczego niezbędne i naturalne jest m.in. uwzględnianie wymiaru kulturowego jako podstawowego czynnika rozwoju.

W najbardziej ogólnym ujęciu kultura holistycznie rozumiana jest traktowana jako ramy i uwarunkowanie rozwoju. Decyduje bowiem o jego dynamice (tworząc bodźce do zmiany) oraz o jego jakości (dostarczając kryteriów oceny zmiany i zmianę ukierunkowując). Twierdzenia te nie wywołują sporów, gdy dotyczą procesów długiego trwania lub odnoszą się do porównań międzykulturowych [Kultura ma znaczenie... 2003].

Badacze nie zadowalają się uogólniającymi stwierdzeniami, lecz dowodzą, że kultura wpływa na rozwój (jego dynamikę i wzory) w krótkich i średnich okresach oraz identyfikuje mechanizmy takiego oddziaływania [Kultura a rozwój... 2013]. Analiza wpływu kultury przechodzi z poziomu makroinstytucjonalnego na poziom mikro, dzięki czemu pozwala formułować bardziej precyzyjne i bardziej adekwatne do danego poziomu rozwoju i kontekstu strukturalnego twierdzenia.

Przykładowo dla wysoko rozwiniętych państw i dojrzałych gospodarek istotna staje się indywidualna przedsiębiorczość i zdolność do samozatrudnienia. W takim kontekście czynniki kulturowe stają się ważne do pobudzania innowacyjności i kształtowania kreatywnych osobowości. Twórcze i samosterowne osoby są niezbędne w epoce rozwoju opartego na wykorzystywaniu wiedzy oraz rosnącego znaczenia przemysłu kreatywnego i technologicznego.

Kultura jest współcześnie traktowana także jako obszar działalności gospodarczej, jako gałąź (lub gałęzie) gospodarki, jako pole inwestowania, tworzenia przedsiębiorstw, oferowania produktów i usług, przyciągania nabywców i uzyskiwania przychodów, dochodów i zysku. W tej perspektywie powszechne staje się stosowanie takich pojęć, jak ,przemysły kulturowe”, które obejmują różnorodne dziedziny, np.: gry komputerowe, produkcję filmową i telewizyjną, spektakle i przedstawienia operowe.

Warto zauważyć, że przywołane perspektywy nie wykluczają się wzajemnie. Pierwszy wskazuje podstawowe, lecz abstrakcyjne prawidłowości typu: „kultura ma podstawowe znaczenie dla rozwoju kraju i jego międzynarodowej konkurencyjności" - nie prowadzą jednak do jasnych wskazań ani co do mechanizmów wpływu, ani co do rynkowej i ekonomicznej wartości konkretnych treści kulturowych, ani co siły i trwałości ich oddziaływania. Są więc teoretycznym uogól- 
nieniem i kierunkowym wskazaniem chroniącym twórców i instytucje kultury przed nadmiernie redukcjonistycznymi ekonomistami zalecającymi udowodnienie bezpośredniej gospodarczej i społecznej użyteczności aktywności twórców i instytucji kultury. Drugi wskazuje, że w wielu krajach, szczególnie w grupie krajów o najwyższych dochodach, zaspokojone zostały podstawowe potrzeby materialne, a dysponujący nadwyżkami finansowymi konsument przesunął swoje zainteresowania na dobra „doświadczeniowe”, które edukują, dostarczają rozrywki, zabawy i innych subiektywnych odczuć i wrażeń, tj. przemysł kulturowy. Celem opracowania jest analiza roli szczególnej instytucji kultury, jaką są muzea, w rozwoju społeczno-gospodarczym. Wskazane zostanie również, jak ewolucja funkcji muzeum zachęca je do rozszerzania zakresu działalności oraz różnicowania źródeł finansowania. Taka transformacja przyczynia się z kolei do wzrostu ekonomicznego znaczenia muzeów. Artykuł zawiera także analizę przesłanek teoretycznych i czynników empirycznych, które wyjaśniają wzrost społecznego i gospodarczego znaczenia muzeów we współczesnych państwach. Przedstawiono dane, które wskazują jak ewolucja funkcji muzeum tworzy bodźce do rozszerzania zakresu ich działalności (typów usług) oraz różnicowania źródeł finansowania. Taka transformacja przyczynia się z kolei do wzrostu ekonomicznego znaczenia muzeów.

\section{Państwo i rynek jako mechanizmy aktywowania czynników kulturowych}

Aktywowanie i wzmacnianie znaczenia czynników kultury w rozwoju gospodarczym i społecznym jest wynikiem zarówno naturalnych, „rynkowych” tendencji, jak i intencjonalnych działań władz publicznych finansujących lub subsydiujących działalność twórców i instytucji kultury. Rozwój przemysłu kultury jest w przeważającym stopniu skutkiem decyzji biznesowych, chociaż i w tym przypadku niezbędne i powszechnie obecne jest ukierunkowujące działanie władz publicznych (przynajmniej we wczesnych fazach rozwoju takich rodzajów przemysłu). Chociaż, jak w wielu innych przypadkach, aktywacja czynników kulturowych w rozwoju gospodarczym podlega uniwersalnym prawidłowościom (przykładowo oczekiwać można, że państwa wyżej rozwinięte przeznaczają więcej środków na instytucje i działalność w obszarze kultury), to każde państwo cechuje się specyficzną dynamiką i konfiguracją sektora kulturowego i przemysłu kulturowego.

W perspektywie historycznej zauważyć należy zmiany motywów zaangażowania państwa w obszar kultury: od celów ideologicznych (wzmacnianie tożsamości) do złożonych celów wzmacniania spójności systemu społecznego oraz 
pragmatycznych celów wspierania dynamiki gospodarczej dzięki przedsiębiorczości (tę zmienność, w znacznie krótszej, gdyż obejmującej trzy dekady perspektywie dobrze ilustruje rys. 1).

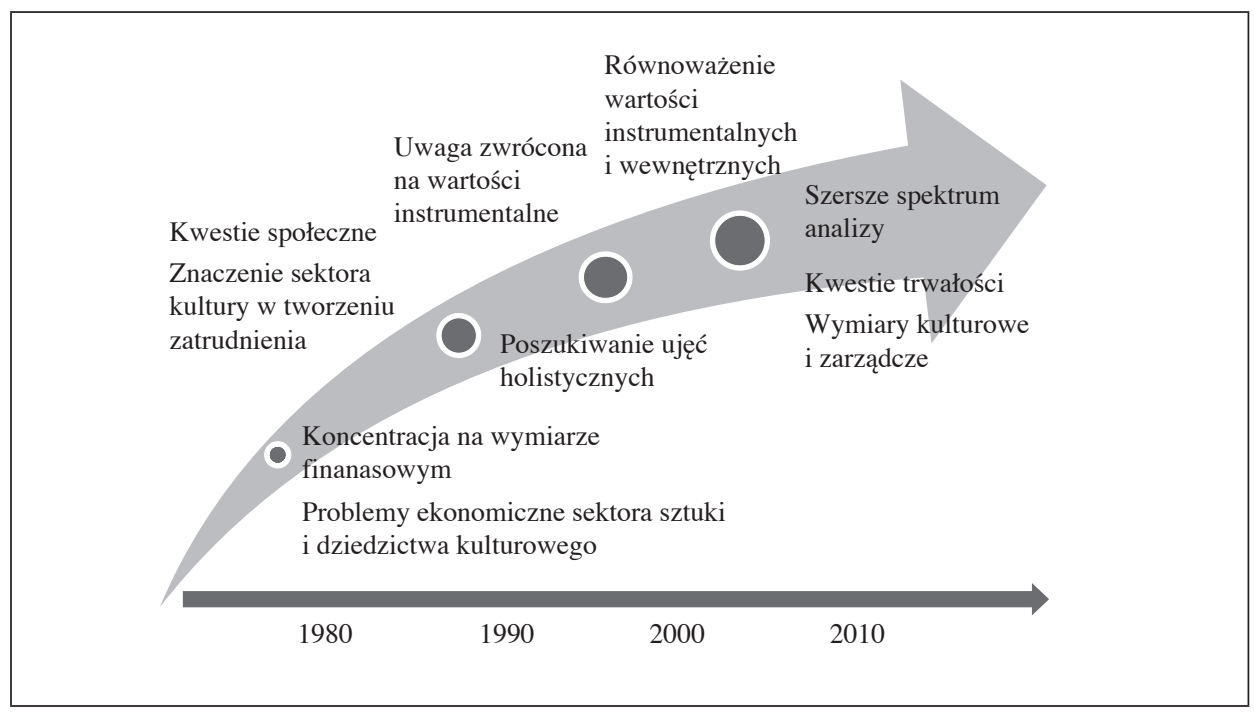

Rys. 1. Ewolucja perspektyw oceny znaczenia muzeów dla rozwoju gospodarczego Źródło: opracowanie własne na podstawie: [Bollo 2013, s. 19].

W niniejszym artykule skupiono się na roli i znaczeniu muzeów dla rozwoju gospodarczego i społecznego. Należy zauważyć, że inwestycje publiczne i prywatne w instytucje kultury oraz dynamika przemysłu kultury mogą w mniejszym lub większym stopniu przekładać się na rozwój instytucji muzealniczych, gdyż w obrębie kultury istnieje znaczna wymienność (substytucyjność) i konkurencja pomiędzy węższymi polami działań kulturowych. Znacząca pozycja muzeów nie jest więc automatycznie gwarantowana. Zależy ona w znacznej mierze od interpretacji funkcji muzeów: gdy jest ona rozumiana wąsko, jako instytucje ukierunkowane na ochronę (odnawianie, naukowa analiza) muzealiów, to muzea w obszarze instytucji kultury cechują się nastawieniem zachowawczym i obroną własnej pozycji. Jeśli funkcje te rozszerzane są o edukację i ,uszlachetnioną" rozrywkę, to dla muzeów otwiera się pole do ekspansji.

Muzea nie oferują produktów pierwszej potrzeby (elastyczność dochodowa popytu na produkty i usługi muzealne jest większa od jeden), ale w wielu państwach przeżywają swój rozkwit. Interesujące jest na przykład, że od 2000 r. do 2012 r. liczba muzeów w Chinach wzrosła z 2000 do 3866, a 2012 r. otwarto tam aż 451 nowych muzeów. W Stanach Zjednoczonych w okresie poprzedzającym 
kryzys finansowy (w latach 1999-2008) otwierano rocznie od 20 do 40 nowych muzeów. Zauważyć należy, że pomimo spektakularnego sukcesu gospodarczego Chiny to wciąż biedny kraj, w którym przeciętny dochód na jednego mieszkańca stanowi zaledwie 1/8 średniego dochodu mieszkańca Stanów Zjednoczonych. Spektakularny rozwój muzeów w Chinach wydaje się więc rezultatem wzrostu zainteresowania przeszłością i decyzji politycznych, które starają się przywrócić mieszkańcom część zniszczonego przez „rewolucję kulturalną” dziedzictwa i dumę ze wspaniałej przeszłości. Tworzenie muzeów w Chinach zyskuje aprobatę mieszkańców. Muzea chińskie odwiedziło 2012 r. 500 mln zwiedzających, czyli 25\% więcej niż w 2009 r. (sto mln zwiedzających więcej) [The Future... 2013]. Znaczące inwestycje w muzea poczyniły także Zjednoczone Emiraty Arabskie. W 2006 r. rząd w Abu Dhabi podpisał umowę z Fundacją Guggenheima, na mocy której do 2017 r. otwarte zostanie tam nowe muzeum, którego gmach zaprojektował Frank Ghery. W 2009 r. parlament Francji zgodził się na powstanie muzeum Louvre w Abu Dhabi, które zostało otwarte w 2015 r. Muzea te są częścią inwestycji, których łączna wielkość w ZEA przekroczyła 27 mld dolarów, dzielnicy kultury w Abu Dhabi, zwiększając turystyczną atrakcyjność tego miasta i kraju.

Przypadek Chin wskazuje na powiązanie rozwoju muzeów z ,wewnętrznym rynkiem" i potrzebami politycznymi. Dla Zjednoczonych Emiratów Arabskich inwestycje w muzea są częścią (oprócz rozwoju transportu lotniczego i usług finansowych) tworzenia nowej, bardziej zróżnicowanej, struktury gospodarki.

Tabela 1. Liczba muzeów i liczba zwiedzających w wybranych krajach (dane z 2010 r.)

\begin{tabular}{|l|c|c|}
\hline \multicolumn{1}{|c|}{ Państwo } & Liczba muzeów (w tys.) & Liczba zwiedzających (w mln) \\
\hline Chiny & 3,9 & 500,0 \\
\hline Hiszpania & 1,5 & 57,5 \\
\hline Holandia & 0,8 & 22,3 \\
\hline Japonia & 5,7 & 161,2 \\
\hline Kanada & 2,5 & 58,8 \\
\hline Korea Płd. & 0,9 & 90,0 \\
\hline Niemcy & 6,3 & 109,6 \\
\hline Stany Zjednoczone & 17,5 & 850,0 \\
\hline Wielka Brytania & 1,7 & 87,6 \\
\hline Włochy & 0,4 & 33,1 \\
\hline
\end{tabular}

Uwaga: definicje muzeów i sposoby pomiaru zwiedzających różnią się pomiędzy krajami.

Źródło: [The Future... 2013].

Decyzje o tworzeniu nowych muzeów lub o skali publicznego finansowania istniejących są wynikiem interakcji pomiędzy decydentami politycznymi, eksper- 
tami (specjalistami z zakresu historii sztuki, architektury czy archeologii) a opinią publiczną. Jest naturalne, że eksperci widzą potrzebę zwiększania skali działania instytucji, z którymi są związani. Decydenci polityczni mogą być rozdarci pomiędzy pragnieniem stworzenia lub dobrego funkcjonowania znaczących instytucji kultury (w tym muzeów) a presją na zmniejszanie wydatków publicznych. Obywatele wspierać mogą rozwój instytucji kultury (w tym muzeów), widząc w nich instytucję wzbogacającą ofertę kulturalną i miejsce zatrudnienia, lecz oponować, jeśli wydatki na nią zmniejszają środki na inne niemniej ważne cele. $\mathrm{W}$ praktyce decydenci polityczni mają sporą autonomię w podejmowaniu decyzji o inicjowaniu instytucji kultury, w tym muzeów. Jednakże trafność tych decyzji jest weryfikowana poprzez jej efekty gospodarcze i społeczne oraz, w ustrojach demokratycznych, polityczną aprobatę lub dezaprobatę w kolejnych wyborach.

Pamiętając o tych trzech grupach podmiotów, warto odróżnić dwa typy sytuacji. Gdy dane muzeum już istnieje, to stanowi ono punkt oparcia (miejsce pracy, przedmiot studiów, miejsce silnego estetycznego i emocjonalnego przywiązania) dla ekspertów. Jeśli nie jest jednak doceniane ani przez polityków, ani przez zwiedzających, to oczekiwać należy spadku poziomu finansowania (publicznego) i zainteresowania społecznego i w rezultacie względną utratę znaczenia danej instytucji i spadek dynamiki jej funkcjonowania. Decyzje polityczne mogą dotyczyć danego muzeum bezpośrednio (poprzez decyzje budżetowe lub nominację zarządzającego) lub pośrednio, gdy dane muzeum zostanie zobowiązane do rosnącego finansowania z dochodów własnych, bez wcześniejszego przygotowania instytucji, wzbogacenia jej oferty i podniesienia poziomu usług. Wprawdzie zasada weryfikacji użyteczności instytucji poprzez test „,kkłonności do zapłacenia" (finansowania ze sprzedaży usług, biletów, pamiątek itp.) za jej usługi jest rozsądną zasadą w większości warunków rynkowych, lecz niekiedy może być skazana na degradację. Strategia zwiększania przychodów własnych instytucji powinna więc być poprzedzona przez trafne i odpowiedniej skali inwestycje modernizujące obiekt i jego usługi.

W drugiej sytuacji podejmowana jest decyzja o utworzeniu nowego muzeum. Jest wtedy, przynajmniej intencjonalnie, silnie związana ze strategią rozwoju danego miasta lub, jeśli państwo jest małe, całego kraju. Decyzja taka może okazać się błędna, ale staje się nie do skorygowania, nie są bowiem znane, przynajmniej w Europie, przypadki bankructwa muzeów i ich zamykania. Inwestowanie w nowe muzea może wynikać z powszechnie akceptowanych oczekiwań politycznych (np. Muzeum Powstania Warszawskiego) lub decyzją o poszerzeniu zakresu instytucji muzealnych o muzeum sztuki współczesnej (np. budowa muzeum sztuki współczesnej MOCAK w Krakowie). Optymalizacja liczby i typów muzeów wymaga rozwiązania układu równań o wielu zmiennych, w tym decyzji o zakresie finansowania publicznego i prób zwiększenia zainteresowania mieszkańców jako odpłat- 
nych zwiedzających lub aprobujących podatników. Większość muzeów, z wyjątkiem egzotycznych muzeów w rodzaju Muzeum Złamanych Serc w Chorwacji czy Muzeum Ołówków w Wielkiej Brytanii, korzysta z publicznego finansowania nie tylko w okresie budowy czy zagospodarowania obiektów, lecz także w celu bieżących wydatków. Zakres publicznego finansowania jest jednak różny i przybiera wartości od 24,4\% w Stanach Zjednoczonych do 90\% w Niemczech. We współczesnych państwach każde nowe muzeum z konieczności staje się rywalem już istniejących w staraniach o udział w finansowaniu publicznym.

W wielu państwach (w szczególności w Europie Zachodniej) trwa kryzys finansów publicznych. W takich warunkach wydaje się naturalne, że rozwój muzeów zależeć będzie od zdolności do wzbudzenia aprobaty wśród obywateli/ konsumentów. Istniejące lub planowane muzea muszą stawać się wrażliwe na oczekiwania zwiedzających i udostępniać im zgromadzone muzealia lub organizowane wydarzenia w sposób je uwzględniający. Potrzeby te będą kształtowane przez procesy demograficzne, w tym widoczne już w Polsce przyspieszone starzenie się społeczeństwa (w innych krajach, w tym we Francji czy Włoszech). Pojawiać się będą inicjatywy muzealne odzwierciedlające zmieniającą się strukturę etniczną tych społeczeństw.

\section{Wielowymiarowość ,produktu muzealnego"}

Uniwersalnym trendem wydaje się „sprzężenie” możliwości, jakie dają nowoczesne technologie (digitalizacja, internet) z poszerzeniem paradygmatu edukacji z formalnej i odgórnej na trwającą całe życie, otwartą i wynikającą z własnej motywacji. Doświadczenie fizycznego kontaktu z obiektem muzealnym jest wzbogacone o treści dostępne z paralelnego digitalnego muzeum. Są to doświadczenia komplementarne. Przygotowanie wirtualnego muzeum, które byłoby narzędziem przekazywania treści edukacyjnych powiązanych ze zgromadzonymi muzealiami wymaga zainwestowania w stworzenie treści i formy o wysokiej jakości - stworzone przez Smithonian Institute wirtualne formy korzystania ze zgromadzonych muzealiów poprzez strony internetowe (www.si.edu) dowodzą olbrzymich możliwości, jakie stwarza ta forma angażowania byłych lub przyszłych zwiedzających. Dzięki „dźwigni digitalnej” muzea mogą stać się ośrodkami tworzenia i przekazywania wiedzy nie mniej skutecznymi, a bardziej atrakcyjnymi niż instytucje formalnego kształcenia. Ze względu na wagę kształtowania kreatywności, wsparte technologiami muzea mogą stać się świetnymi ośrodkami promowania twórczego myślenia, pracy zespołowej i twórczego zespołowego rozwiązywania problemów. 


\section{Problemy pomiaru a ewaluacja instytucji kultury}

Współcześnie instytucje publiczne i organizacje prywatne poddawane są wszechstronnej ocenie (niekiedy powiada się, że żyjemy w społeczeństwie audytu). Oznacza to, że nadzorcy i partnerzy instytucji publicznych, w tym muzeów, chcą uzyskać zobiektywizowany obraz ich funkcjonowania, korzystając ze skonstruowanych wskaźników i innych metod pomiaru. Należy przypuszczać, że chociaż pojedyncze lub syntetyczne wskaźniki nigdy nie są doskonałe, to, jeśli są one starannie dobrane i systematycznie stosowane pozwalają na rzetelniejszą kontrolę działania instytucji przez jej nadzorców oraz umożliwiają uczenie się i doskonalenie działania przez zarządzających tą instytucją (niezależnie od odgórnych kontroli). Podstawowe wskaźniki wyników pracy instytucji można podzielić na:

- wskaźniki jakości, w tym stopień osiągania celów, opinie środowiska, oceny przez zwiedzających,

- wskaźniki efektywności, w tym zgodności z harmonogramami, zgodności z planem finansowym,

- wskaźniki skuteczności, w tym bezpieczeństwa, wynagradzania, bariery dostępu,

- wskaźniki reaktywności, w tym świadomości konkurencji, wyzwań i zagrożenia.

Pomiar i ocena wyników instytucji kultury jest nierozwiązanym (i być może niemożliwym do rozwiązania) problemem teoretycznym i problemem praktycznym. W wymiarze teoretycznym podstawowa trudność wiąże się z pomiarem wartości korzyści, które nie mają i nie są sprowadzalne do wymiaru pieniężnego. Koszty funkcjonowania instytucji kultury (w tym muzeów) są w większości wyrażalne w pieniądzu (nakłady finansowe ponoszone na odnowienie, utrzymanie i funkcjonowanie obiektu, w tym prace inwestycyjne, zakup wyposażenia oraz płace personelu), natomiast korzyści, oprócz przychodów ze sprzedaży biletów i pamiątek, nie jest wyrażalna w pieniądzu. Przykładowo na pytanie, jaka jest wartość Koloseum, padają odpowiedzi typu: jest bezcenne lub nie jest na sprzedaż. Wartość istnienia zachowanego z przeszłości obiektu jest niewyrażalna w pieniądzu, a wyjątkowość (unikatowość) obiektów sprawia, że nie pojawia się wycena rynkowa, o ile w ogóle dany obiekt mógłby być przedmiotem transakcji sprzedaży/kupna (pamiętać należy, że często zgromadzone w muzeach kolekcje zostały tam przekazane przez prywatnych darczyńców z zastrzeżeniem, że nie mogą one zostać sprzedane czy przekazane gdzie indziej).

W takich warunkach wartość obiektów oraz muzealiów jest wartością hipotetyczną i można o niej wnioskować, zadając pytania typu: jeśli rada miasta zdecydowałaby się przestać finansować muzeum (lub jeśli zdecydowałaby się sprzedać najcenniejszy obraz w jego kolekcji), to ile dana osoba byłaby skłonna 
dobrowolnie wpłacać co miesiąc na konto muzeum, aby utrzymać jego działanie (lub zatrzymać dany obiekt)?

Wartość uzyskanych w ten sposób odpowiedzi jest przedmiotem sporu. Wobec trudności w kwantyfikacji korzyści płynących z funkcjonowania obiektu kultury badacze posługują się miarami pośrednimi. Warto przedstawić bardzo rozpowszechnioną typologię społecznego wpływu muzeum opracowana przez F. Matarasso [1997]. Wśród pozytywnych skutków funkcjonowania instytucji kultury wymienić należy:

- przyczynianie się do budowy poczucia własnej wartości, która ułatwia tworzenie więzi wspólnotowych,

- wzrost zaangażowania w życie społeczne,

- budowę wsparcia dla inicjatyw wspólnotowych,

- wzmacnianie wpływu ludzi na to, jak są postrzegani z zewnątrz,

- wzmocnienie skłonności do współpracy,

- pobudzenie zainteresowania sztuką,

- budowanie dumy z własnych tradycji i kultury,

- tworzenie płaszczyzny do podejmowania odpowiedzialności za losy wspólnoty,

- pomoc w uzyskaniu poczucia przynależności,

- wspieranie edukacji i rozwoju dzieci,

- tworzenie wspólnoty tradycji w nowych miastach lub w nowym sąsiedztwie,

- budowanie zaangażowania na rzecz poprawy jakości środowiska,

- pomoc w nabywaniu nowych umiejętności i doświadczenia pracy,

- poprawę wizerunku grup zmarginalizowanych,

- otwieranie możliwości rozwoju karier w zawodach artystycznych,

- zasypywanie luki pomiędzy twórcą a konsumentem,

- tworzenie forum dla międzykulturowego porozumienia,

- otwieranie możliwości dla rozwijających form wolontariatu,

- ułatwianie procesów publicznej konsultacji i wspólnotowej partycypacji,

- dostarczanie wyjątkowej i pogłębionej satysfakcji.

Stosowane do oceny skutków funkcjonowania instytucji kultury (w tym muzeum) wskaźniki mają na celu uchwycenie takich właśnie niefinansowych („niewyrażalnych w pieniądzu”) skutków.

Tworzone na użytek muzeów wskaźniki oceny pracy powinny być dostosowane do typu i skali danego muzeum. Inne są bowiem uwarunkowania i możliwości muzeów, które zaliczane są to grupy „superstars”, gdyż posiadają bogatą kolekcję i są zlokalizowane w światowych metropoliach, inne natomiast małych lokalnych muzeów. W przypadku Polski także istnieją muzea (oraz ośrodki muzealne), korzystające z „renty lokalizacji” i dzięki niej większej możliwości przyciągania zwiedzających i generowania dodatkowych przychodów. Dla rozwoju całego 
sektora muzeów w Polsce korzystne mogłoby być stworzenie swoistego „funduszu solidarności muzealnej”, którym muzea bogatsze w środki dzieliłyby się przychodami z muzeami biedniejszymi. Inną pożądaną formą ,wyrównywania szans muzealnych" byłoby nieodpłatne wypożyczanie niektórych muzealiów muzeom w mniejszych ośrodkach.

Tabela 2. Największe muzea świata pod względem liczby zwiedzających

\begin{tabular}{|l|c|c|c|}
\hline \multicolumn{1}{|c|}{ Muzeum } & Kraj & Rok utworzenia & $\begin{array}{c}\text { Liczba zwiedzających } \\
\text { (w mln) }\end{array}$ \\
\hline Tate Modern & Londyn/Wielka Brytania & 2000 & 5,3 \\
\hline Pompidou Centre & Paryż/Francja & 1977 & 3,8 \\
\hline $\begin{array}{l}\text { Museum of Modern } \\
\text { Art }\end{array}$ & New York/USA & 1929 & 2,8 \\
\hline Reina Sofia & Madryt/Hiszpania & 1992 & 2,6 \\
\hline Saatchi Gallery & Londyn/Wielka Brytania & 1985 & 1,4 \\
\hline $\begin{array}{l}\text { Institute of Modern } \\
\text { Art }\end{array}$ & Valencia/Hiszpania & 1989 & 1,3 \\
\hline $\begin{array}{l}\text { National Museum } \\
\text { of Modern } \\
\text { and Contemporary Art }\end{array}$ & Seul/Korea Płd. & 1969 & 1,3 \\
\hline Guggenheim Museum & New York/USA & 1939 & 1,2 \\
\hline Museu Picasso & Barcelona/Hiszpania & 1963 & 1,1 \\
\hline Mori Art Museum & Tokyo/Japonia & 2003 & \\
\hline
\end{tabular}

Źródło: [The Future... 2013].

Funkcjonowanie muzeów można postrzegać jak proces przetwarzania nakładów w różne typy wartości, produktów i społecznych oddziaływań (skutków). Z punktu widzenia niektórych podmiotów szczególnie ważne są niektóre typy skutków. Publiczny założyciel i fundator muzeum może być zainteresowany zarówno skutkami ekonomicznymi (finansowymi), jak i skutkami społecznymi i kulturowymi, które są sednem jego misji. Ocena skutków ekonomicznych nie jest jednak zredukowania do kryterium maksymalizacji zysków, lecz kryterium osiągania zadowalających dochodów, które pozwalają na kontrolowanie skali transferów (dotacji) na rzecz danej instytucji publicznej. Cele i kryteria oceny stosowane przez prywatnego założyciela i fundatora muzeum nie odbiegają co do kategorii od celów i kryteriów oceny założyciela i fundatora publicznego. Różnice w wadze przydawanej kryteriom finansowym (ekonomicznym) wynikają z tego, że fundator prywatny podlega większym ograniczeniom budżetowym („twarde ograniczenia budżetowe"), podczas gdy fundator i założyciel publiczny działa w warunkach „miękkiego ograniczenia budżetowego”. 
Rozróżnienie typu skutków, w tym skutków ekonomicznych, społecznych i kulturowych, pozwala dostrzec możliwość pełnienia szerszych funkcji przez instytucje prywatne. W tej perspektywie warto przywołać szczególne rozwiązania instytucjonalne w Wielkiej Brytanii, gdzie współistnieją instytucje kultury (m.in. British Museum) w pełni finansowane przez państwo (nie ma w nich opłat wejściowych) oraz instytucje prywatne, w tym działające w ramach English Heritage [Kelly 2006], które są własnością prywatną, są zarządzane przez prywatne podmioty, lecz korzystają z ulg podatkowych (w tym ulg w podatku od spadku) pod warunkiem zapewnienia minimalnej publicznej dostępności obiektu dla zwiedzających.

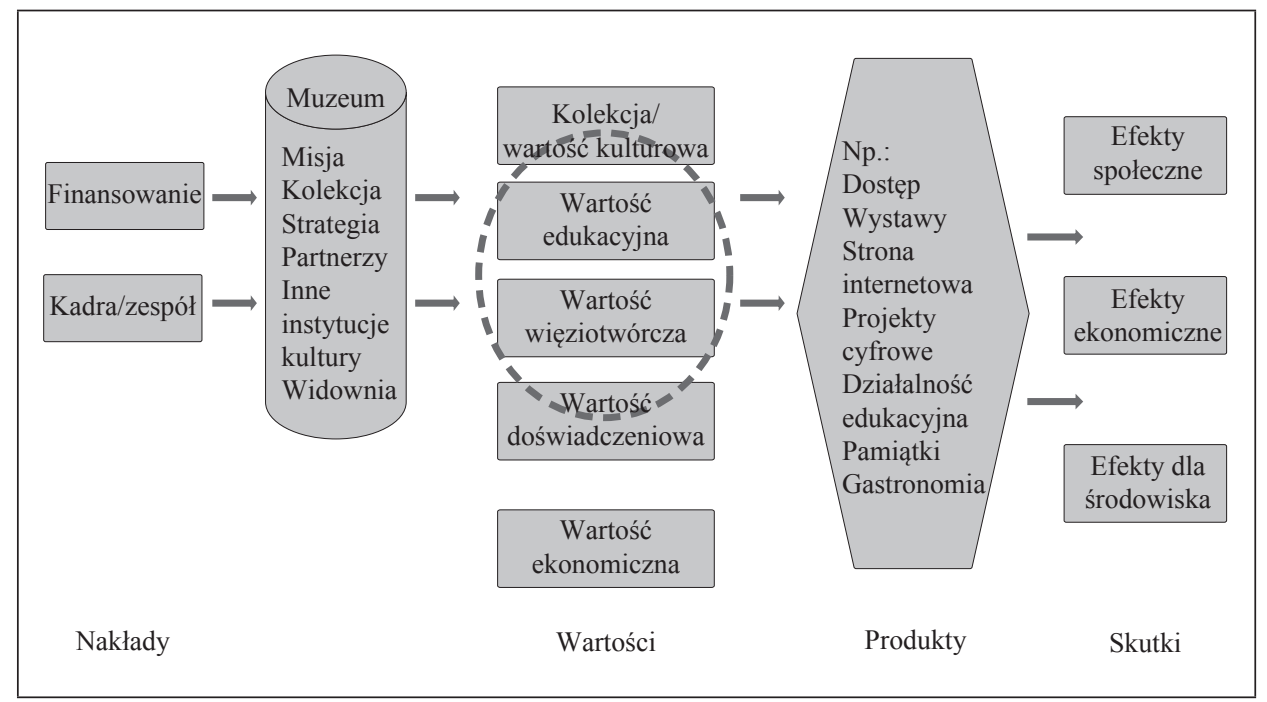

Rys. 2. Działalność muzeów w perspektywie analizy kosztów i korzyści Źródło: [Bollo 2013, s. 14].

Pełna analiza kosztów i korzyści (rys. 2) funkcjonowania instytucji kultury (w tym muzeum) pozwala dostrzec, że istnieje wiele rozwiązań umożliwiających równoważenie celów krótkookresowych (w wymiarze finansowym i ekonomicznym można dostrzec dominację celów krótkookresowych) z celami długookresowymi.

Każda instytucja kultury (w tym muzea) powinna być oceniana ze względu na rozwiązania organizacyjne oraz jakość procesów zarządzania. Do niedawna na przykład muzea włoskie były w przeważającej mierze jednostkami budżetowymi administracji i nie posiadały odrębnych budżetów. Sytuacja taka z pewnością 
ogranicza samodzielność decyzyjną zarządzających instytucjami, ale równocześnie zmniejsza ich odpowiedzialność za efekty ekonomiczne.

Warto przypomnieć, że wszystkie instytucje kultury, w tym muzea, mają wymiar ekonomiczny (zużywają zasoby gospodarcze), lecz nie powinny być do niego redukowane. Oznacza to, że w praktyce mogą zaistnieć rozmaite typy sytuacji, w tym wyłączny nacisk na wyniki ekonomiczne nawet kosztem degradacji wartości kulturowych (przykładowo długookresowe wypożyczenie najcenniejszych muzealiów w celu uzyskania środków finansowych na bieżące funkcjonowania instytucji) lub, krańcowo odmienny, wyłączny nacisk na efekty artystyczne/estetyczne bez uwzględniania konsekwencji finansowych. W praktyce mamy jednak do czynienia z wyborami typu „więcej lub mniej” nacisku na dany wymiar. Oznacza to konieczność uwzględniania „krzyżujących się” (wzajemnych) wpływów decyzji podyktowanych względami kulturowymi (artystycznymi) na wymiar finansowy i odwrotnie.

Chociaż współczesne muzea wyłoniły się z prywatnych inicjatyw kolekcjonerskich, to obecnie stały się instytucjami publicznymi i organizacjami o złożonych procesach wewnętrznych i wielorakich skutkach zewnętrznych. Oznacza to, że wzrasta poziom wymagań od osób kierujących takimi placówkami. Powinni oni łączyć minimalne kompetencje eksperckie w danej dziedzinie, z którą wiąże się misja muzeum, z kompetencjami w zakresie zarządzania oraz marketingu. Każde muzeum zatrudnia bowiem pomocniczy personel administracyjny, techników, edukatorów, kuratorów i specjalistów od komunikacji społecznej w proporcjach, które powinny pozwalać w zadowalającym stopniu osiągnąć założone cele. Zarządzający wraz ze współpracownikami powinien podejmować nowe inicjatywy, które zwiększają środki niezbędne dla działalności placówki (w Polsce na przykład rzadko lub wcale nie są wydawane Muzealne Karty Klubowe, które pozwalają darczyńcom uzyskać specjalny status) lub mobilizują do pracy na rzecz muzeum wolontariuszy ( $w$ wielu państwach wolontariat jest ważną formą wspierania funkcjonowania placówek muzealnych).

Dla funkcjonowania muzeów rosnące znaczenie ma jakość tworzonych przez muzea materiałów cyfrowych. O ile udostępnianie cyfrowych muzealiów rodzi bezpośrednie koszty (stworzenie wysokiej jakości cyfrowych materiałów jest kosztowne) i może nie przynosić wzrostu przychodów (niektóre muzea, w tym Rijksmuseum w Amsterdamie nieodpłatnie udostępniają wysokiej rozdzielczości cyfrowe fotografie zgromadzonych kolekcji), gdyż celem nie jest uzyskanie wartości ekonomicznej dla muzeum, lecz zwiększenie „wartości doświadczeniowej", o tyle stworzenie cyfrowych materiałów wyzwala przeżycia estetyczne, kreatywność albo odpoczynek oraz wiąże użytkownika z daną instytucją.

Ograniczenie analizy funkcjonowania muzeum do bezpośrednich skutków ekonomicznych dla gospodarki lokalnej (rys. 3 wskazuje kolejne kroki takiej 


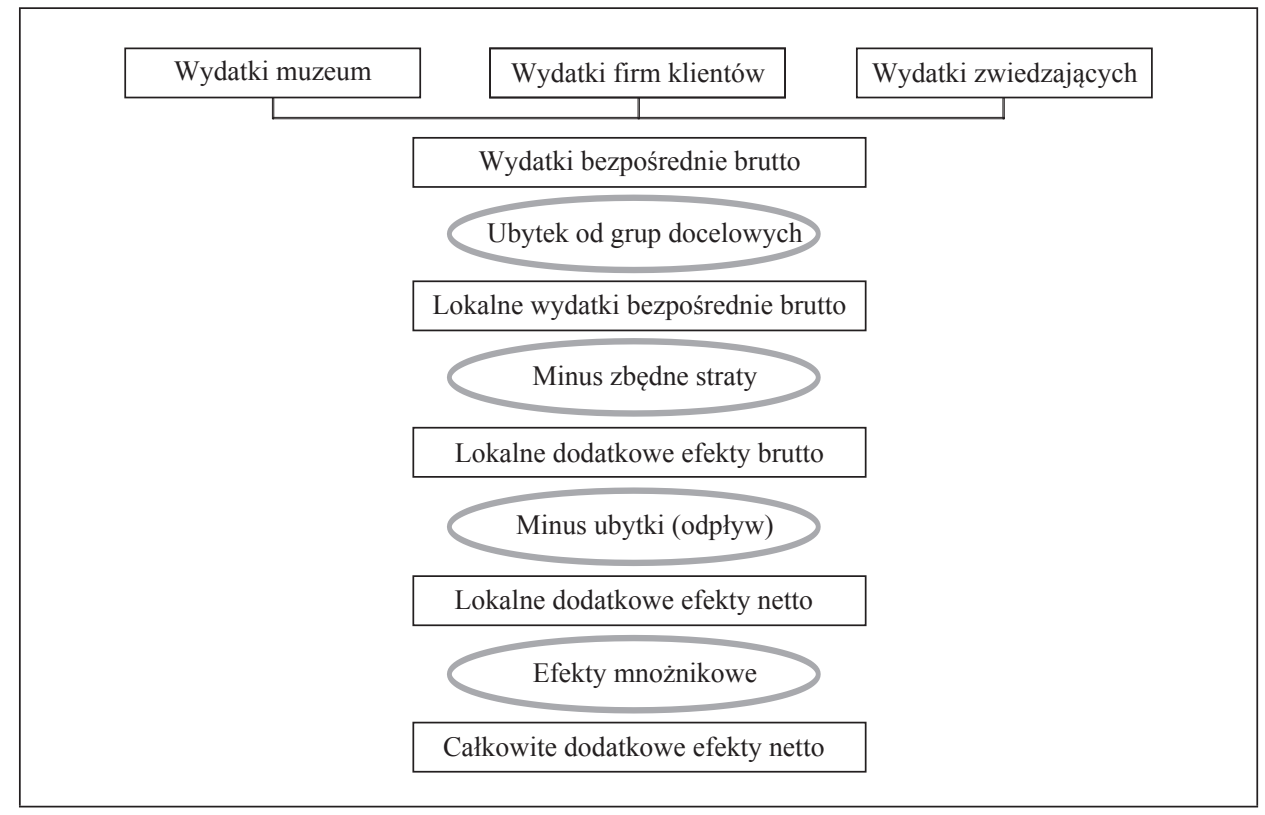

Rys. 3. Wydatkowe podejście do oceny ekonomicznych skutków funkcjonowania muzeum dla lokalnej gospodarki

Źródło: [Bollo 2013, s. 31].

analizy) może prowadzić do utraty zdolności do ich wartościowania. Z analizy wielkości lokalnych wydatków może na przykład wynikać, że dla lokalnej gospodarki korzystniejsze jest przykładowo istnienie jednostki wojskowej, gdyż wojskowi i ich rodziny wydają więcej pieniędzy. Znaczenie instytucji kultury (muzeum) wynika z etycznego i estetycznego wartościowania, w którym obywatele, mieszkańcy i konsumenci decydują o tym co i jak cenią.

Tabela 3. Odsetek respondentów, którzy zwiedzili muzeum lub galerię w ciągu ostatnich 12 miesięcy

\begin{tabular}{|c|c|c|c|c|c|c|c|c|c|}
\hline Szwecja & $\begin{array}{c}\text { Holan- } \\
\text { dia }\end{array}$ & $\begin{array}{c}\text { Wielka } \\
\text { Brytania }\end{array}$ & Niemcy & Francja & Włochy & $\begin{array}{c}\text { Hiszpa- } \\
\text { nia }\end{array}$ & Polska & $\begin{array}{c}\text { Portuga- } \\
\text { lia }\end{array}$ & Grecja \\
\hline 76 & 60 & 52 & 44 & 39 & 30 & 29 & 24 & 17 & 16 \\
\hline
\end{tabular}

Źródło: [Cultural Access... 2013].

Kwestia społecznego doceniania dziedzictwa kulturowego i oferty instytucji kultury wskazuje na wagę edukacji w kształtowaniu zainteresowania takimi ofertami [Murzyn-Kupisz 2012]. Popyt na dziedzictwo kulturowe nie jest kształtowany przez masowe kampanie reklamowe, lecz wymaga długookresowej konsekwentnej 
pracy nad kształtowaniem gustu. Edukacja jest tym dla doceniania dziedzictwa, czym reklama dla rozrywki. Przyciąganiu i rozwojowi zwiedzających służy przekształcanie muzeów - w sformułowaniu Victorii Newhouse [2007] - „wstrzemięźliwych zbiorów” (restrained containers) w „żywiołowych towarzyszy” (exuberant companion), którzy oferują poszerzone doświadczenia dla zwiedzających i innych użytkowników (w tym uczestników konferencji).

\section{Wnioski}

Prawie sto lat temu B.I. Gilman [1918], który przez ponad 30 lat kierował Boston Museum of Fine Arts, opublikował pracę Museum Ideals: of Purpose and Method, w której zalecał kierującym muzeami, aby traktowali je jako swoiste obiekty sakralne, które cechuje samoistna wartość estetyczna niewymagająca żadnego usprawiedliwienia, wyjaśnienia, kontekstualizacji i żadnej narracji. Pisał on: „Muzeum sztuki jest w swojej istocie świątynią”.

W czasach Gilmana muzea zwracały się do wąskiej elity społeczeństwa. Współcześnie chcą trafiać do masowych odbiorców. Polityczni decydenci oraz osoby bezpośrednio kierujące tymi instytucjami muszą więc rozumieć specyficzny ,proces produkcyjny”, w wyniku którego nakłady publiczne i prywatne są efektywnie przetwarzane w produkty kulturowe, które zyskują zainteresowanie zwiedzających i w rezultacie przyczyniają się do powstania pochodnych korzystnych efektów społecznych i gospodarczych.

Ze względu na publiczną wartość dziedzictwa kulturowego rząd oraz władze lokalne odpowiadają za inwestycje w ochronę dziedzictwa kulturowego i w szczególności w niektóre muzea. Brak albo niewystarczające finansowanie czyni te placówki mało atrakcyjnymi, zmniejsza zainteresowanie zwiedzających i uzasadnia uznawanie ich za zbędne. W ten sposób mogą powstawać „negatywne sprzężenia zwrotne" i doprowadzać do samospełnienia własnych założeń. Inwestycje odpowiedniej skali połączone z wizją odnowionej lub zmodernizowanej instytucji mogą z kolei pobudzić jej rozwój i pozwolić na wzrost atrakcyjności i wyższego poziomu samofinansowania ${ }^{1}$.

1 Wzorem takiego typu działania stała się budowa muzeum Guggenheima w Bilbao. W ciągu trzech pierwszych lat po otwarciu muzeum rząd Kraju Basków zyskał dzięki zwiększonym wpływom podatkowym ponad $100 \mathrm{mln}$ euro i w ciągu tego krótkiego okresu odzyskał poniesione nakłady. W 2012 r. muzeum to odwiedziło ponad $1 \mathrm{mln}$ zwiedzających, z czego ponad połowa z zagranicy [The Future... 2013]. 


\section{Literatura}

Bollo A. [2013], Measuring Museum Impact, LEM Report 3, http://online.ibc.regione. emilia-romagna.it/I/libri/pdf/LEM3rd-report-measuring-museum-impacts.pdf.

Cultural Access and Participation. Report [2013], Special Eurobarometer 399, ec.europa. eu/public_opinion/archives/ebs/ebs_399_en.pdf (dostęp: 6.10.2015).

Ekonomia muzeum [2011], red. D. Folga-Januszewska, B. Gutowski, Universitas, Kraków. Gilman B.I. [1918], Museum Ideals of Purpose and Method, Riverside Press, Cambridge.

Heritage Counts: The State of England's Historic Environment [2006], www.englishheritage.org.uk (dostęp: 6.10.2015).

Kultura a rozwój [2013], red. J. Hausner, A. Karwińska, J. Purchla, Narodowe Centrum Kultury, Warszawa.

Kultura ma znaczenie. Jak wartości wpływaja na rozwój społeczeństw [2003], red. L.E. Harrison, S.P. Huntington, Zysk i S-ka, Poznań.

Kelly L. [2006], Measuring the Impact of Museums on Their Communities: The Role of the $21^{\text {st }}$ Century Museum, http://www.intercom.museum/documents/1-2Kelly.pdf (dostęp: 19.08.2015).

Matarasso F. [1997], Use or Ornament? The Social Impact of Participation in the Arts, Comedia, Stroud.

Murzyn-Kupisz M. [2012], Dziedzictwo kulturowe a rozwój lokalny, Zeszyty Naukowe Uniwersytetu Ekonomicznego w Krakowie, Seria specjalna: Monografie, nr 221, Kraków.

Newhouse V. [2007], Towards a New Museum, Monacelli Press, New York.

Stiglitz J.E., Sen A., Fitoussi J.P. [2013], Bład pomiaru. Dlaczego PKB nie wystarcza, PTE, Warszawa.

The Future of Museums [2013], ,The Economist”, 21 grudnia.

\section{The Role of Museums in the Social and Economic Development of Contemporary States}

(Abstract)

The article is a theoretical analysis identifying the sources of the growth in importance of museums in many contemporary societies. It shows how the evolution of museum functions broadens the range of their activities and encourages them to diversify financing. Such a development contributes in turn to the growth of the economic significance of museums.

The article also discusses methodological problems that make it very difficult to identify the optimum level and modes of public financing. It also points to the non-pecuniary nature of social benefits as the main cause with the economic optimisation of public subsidies to museums.

The article argues that the quantitative expansion of the sector of museums stems in large part from their transformation from an institution of heritage protection into institutions of informal education and entertainment.

Keywords: economic analysis of cultural institutions, economic analysis of museums, cost-benefit analysis, creative industries. 